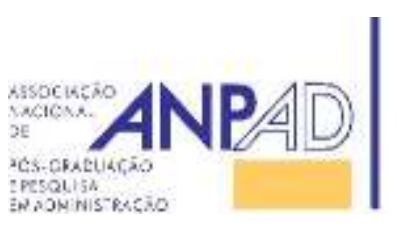
Available online at http://www.anpad.org.br/bar
BAR, Rio de Janeiro, v. 13, n. 2, art. 1, e160007, Apr./June 2016 http://dx.doi.org/10.1590/1807-7692bar2016160007 (ल) EY

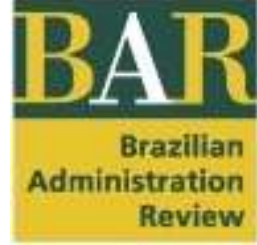

\title{
Do the Board of Directors Composition and the Board Interlocking Influence on Performance?
}




\begin{abstract}
This study analyzes the influence of composition of the Board of Directors and their social relations (board interlocking) on performance of Brazilian companies. A descriptive study based on documentary research was conducted with a total of 1,163 companies' observations and 18,119 standardized observations regarding directors. Simultaneous equations were applied to the data analysis. The survey results showed that, regarding the influence of composition of the Board of Directors on the performance of the companies, among variables used to identify its characteristics, that some showed endogeneity. Among the characteristics of the Board of Directors, the duality of the board was exogenous when comparing market performance (Tobin's Q) and the outsiders were also exogenous for internal performance (Return on Equity). Thus, the duality of the board is more influenced by the specificities of each company than by the market value of the companies. The characteristic outsiders are more influenced by the institutional environment than by the ROE. The practice of board interlocking proved to be insignificant in relation to the market value, indicating natural selection. Therefore, it is not possible to infer that the board interlocking can increase the dependency of the management, compromising the role of monitoring. Also, it is not possible to state that better positioned and central companies in the corporate relationships network show better performance.
\end{abstract}

Key words: board of directors; board interlocking; performance of companies. 


\section{Introduction}

Studies on the Board of Directors as a mechanism of control and its effects on performance, from the perspective of the Agency Theory, have been conducted from Fama (1980) and Fama and Jensen (1983a) on. On the same line, there are studies from Baysinger and Butler (1985), and Kosnik (1987) and, after these, of Prevost, Rao and Hossain (2002), and Lefort and Urzúa (2008). Questions about the efficiency of the Board of Directors as a mechanism of control are directly involved in the agency conflict. From the perspective of the Agency Theory, the board interlocking contributes to the coordination and management of conflicts between principal and agent, with intention of improving performance (Caswell, 1984). The interlock occurs when a professional is an executive in a company and a member of the board in another one.

The internal mechanisms of corporate governance, recommended by the Agency Theory, work on organizational performance. Companies that separate ownership and control use mechanisms of control to promote the alignment of interests between principal and agent, to reduce their agency costs. Directors interact in other companies, sharing the interlocking, in order to, when positive, bring benefits to monitoring, once they may have greater power/prestige and get better information about the ability of the agents within the group. Better internal mechanisms of control and interlock sharing in the companies result in better performance. However, this logic is not always perfect, the effects of the social relationships may have a negative effect on performance (Labianca \& Brass, 2006).

Mizruchi (2004) points out some reasons for setting interlocks, such as collusion, monitoring, legitimacy, career development and social cohesion. On the origin and the effect of interlocks, Mizruchi (1996) points out five perspectives: (a) interlocking is a way of co-opting and/or monitoring; (b) provides the companies with information on business practices; (c) only reflects the high class cohesion; (d) hypothesis of occupation; (e) observes board interlocking as a sociological phenomenon, as a means to consolidate and maintain control over the sector. The first two points of view indicate positive influence of interlocking on the performance of the company. In contrast, the hypothesis of occupation indicates negative influence on the performance of the company. The effect of board interlocking can be positive, negative or neutral, when it reflects high class cohesion (Non \& Franses, 2007) and, when it reflects the sociological phenomenon, it can be, besides positive or negative (Labianca \& Brass, 2006).

That being said, the question that guides this study is: What is the influence of the composition of the Board of Directors and the social relations on the performance of Brazilian companies? Thus, the objective of this study is to verify the influence of the composition of the Board of Directors and the social relations (board interlocking) on the performance of Brazilian companies. The population of the survey is composed by the companies listed on BM\&FBovespa in the period from 2007 to 2012, except financial and insurance companies.

Prevost et al. (2002), and Lefort and Urzúa (2008) pointed out that few studies observed the endogeneity of the composition of the Board of Directors on the performance of the companies. Pombo and Gutiérrez (2011) state that there is a not yet solved gap in the research investigating Board of Directors, board interlocking and performance. Inserting the factors presented in the research contributes to the development of the proposed theme. It was found out in national and international journals that the theme composition of the Board of Directors and performance of the companies, when investigated from the perspective of the Agency Theory, usually does not focus on social and political ties, which this study investigates through analysis indicators of social networks.

The study seeks to advance in the research by associating the economic factors of the performance of the companies and the internal mechanisms of control of corporate governance, the sociological elements arising from the composition of the Board of Directors and the board interlocking. In this context, the social relations of the senior management members have relevance in company performance (Mendes-da-Silva, 2011), as well as the interaction of behavioral relations in administrative practices of companies, as economic ties often result in social relations that impact decision making process at corporate level, according to the concept introduced by Smith (1776). 
Studies carried out in Brazil on the Board of Directors (Andrade, Salazar, Calegário, \& Silva, 2009; Gondrige, Clemente, \& Espejo, 2012; Martins, Mazer, Lustosa, \& Paulo, 2012; Santos \& Silveira, 2007; Silveira, Barros, \& Famá, 2003) observed these elements separately and did not investigate the social and economic ties. Internationally, studies investigated characteristics such as insiders/outsiders, independence, duality, size (Arosa, Iturralde, \& Maseda, 2010a; Chahine \& Goergen, 2013; Cheng, 2008; Ramos \& Olalla, 2011; Rosenstein \& Wyatt, 1990; Yermack, 1996). However, these studies do not highlight its sociological elements.

This study is an advance to the research of these authors, with the inclusion of sociological elements. Also differs from the study of Mendes-da-Silva (2011) by investigating whether social ties among directors affect company's performance, considering concentration of company Property Structure It states that the interlocking between companies happens through the sharing of the control (family-owned companies), insider and institutional shareholders and by sharing of directors.

Another important factor is choosing the unit of analysis in governance structures of an inefficient market, with concentrated ownership structure. Most empirical studies investigating the composition of the Board of Directors and their social relations in company performance focused on the analysis of companies with dispersed Ownership Structure. Brazilian companies that have concentrated ownership, are controlled by business groups, which share administration of several companies (conglomerates). Thus, a group of business differs from dispersed property by the presence of a previously formed social structure (Granovetter, 1994).

The benefits of interlocking are pointed out in various researches (Mendes-da-Silva, Rossoni, Martin, \& Martelanc, 2008), arguing that connecting to different networks or groups increases the chances of benefits, but these networks are more important in environments of uncertainty than in less uncertain environments. By sharing directors, companies form networks of relationships, which contribute to management and acquisition of benefits, maintenance and improvement of control mechanisms. However, not always these sharing are beneficial to businesses, whereas, social ties maintained by the asymmetry of values and preferences of the actors in the network, due to differences of thought, values, behavior and patterns, impede the maintenance of common goals (Labianca \& Brass, 2006).

Therefore, through the lens of the Agency Theory, in a functionalist logic, the combination of economic mainstream aspects, in particular the Board of Directors' composition, with the sociological paradigm, through the social relations of interlocking between directors, and their influence with the performance of the companies, is a gap perceived in the review of the literature. The Agency Theory advocates that the individual characteristic of Resourceful, Evaluative and Maximizing Model (REMM) is rational and maximizes its self-interest (Jensen \& Meckling, 1976). However, in addition to being economic, the individual is sociological, psychological and political (Meckling, 1976). In this sense, the study seeks to contribute with filling this research gap observed in the literature.

\section{Literature Review}

\section{Board of Directors and performance of the companies}

The Board of Directors, according to Rosenstein and Wyatt (1990), Rhoades, Rechner and Sundaramurthy (2000), Ramos and Olalla (2011), and Chahine and Goergen (2013), has a positive effect on corporate performance, characterized as an endogenous variable as discussed by Hermalin and Weisback (1988) and tested empirically by Barnhart and Rosenstein (1998), and Lefort and Urzúa (2008).

Black, Jang and Kin (2006) found out that the increase of the number of independent directors is consistent with the increase in the market value of the companies. On the other hand, companies can 
change the composition of the Board of Directors in response to the performance of the company. Hermalin and Weisbach (1988) stated that companies can increase the number of independent directors to improve results or, when facing investment opportunities and high rates of Tobin's Q, they may want to increase the proportion of independent directors to attract investors.

In this study, it is expected that the characteristics of the Board of Directors present significant and simultaneous effect on the performance of the companies. Thus, the first hypothesis was formulated:

H1: The composition of the Board of Directors, observed by its characteristics and by the board interlocking, determines the performance of the companies, when the endogeneity is controlled.

With this hypothesis it is expected, if endogeneity is characterized in the composition of the Board of Directors and the performance of the companies, to find similar results as found out by Hermalin and Weisbach (1988, 2003), Cho (1998) and Lefort and Urzúa (2008), that indicate simultaneous effects in the directions of the variables, i.e., that the composition of the Board of Directors produces simultaneous effects on performance. Therefore, the composition of the Board of Directors can increase the value of the companies, but performance may also determine the characteristics of the composition of the Board of Directors.

\section{Characteristics of the Board of Directors and performance of the companies}

The presence of high proportions of independent directors on the Board of Directors may increase the effectiveness in reducing the agency problem (Setia-Atmaja, Haman, \& Tanewski, 2011). In order to constitute the Board of Directors as an effective body, companies prioritize in their composition mainly independent directors. Two areas of investigation of the Board of Directors that use this assumption are the duality CEO/chairman and insider/outsider director (Zahra \& Pearce, 1989). The composition of the Board of Directors with more outsider members, according to Agrawal and Knoeber (1996), is negatively related to performance. For the authors, the composition can be expanded for political reasons, and these outsider directors reduce the performance in a direct manner or for political reasons, which keeps them in their position.

Baysinger and Butler (1985), Barro and Barro (1990), Yermack (1996), Bhagat and Black (1999), and Klein (1999) related the Board of Directors with Tobin's Q and found out more significant relationships, once Tobin's $\mathrm{Q}$ is a performance indicator that reflects the intangible assets of a company, according to Hermalin and Weisbach (2003). Yermack (1996) found out a significant relationship of inverse association between the size of the Board of Directors with Tobin's Q, and found out more favorable values for financial indicators (Return on Assets - ROA). The author explains that this positive relationship between the Board of Directors and ROA was perceived for small Boards.

However, the results of Yermack (1996) and Cheng (2008) provide empirical evidence that companies with larger Board of Directors have less variability in corporate performance. The results indicate that the size of the Board of Directors is negatively associated with the variability of stock returns, ROA and Tobin's Q. The results are consistent with the view that it is necessary greater effort for a Board of Directors to reach consensus. Thus, decisions of the Board of Directors with larger sizes are less extreme, leading to less variability in performance. The author states that this is consistent with the view that the number of extreme decisions of the Board of Directors decreases according to the size of the Board of Directors.

It is possible to notice a relationship between the composition of the Board of Directors and the performance of the companies. Thus, the second hypothesis was formulated:

H2: The characteristics of the composition of the Board of Directors (outsiders, independents, professionals, duality and size) have positive influence on the performance of the companies.

Thus, the hypothesis can be tested by segregating the composition of the Board of Directors by its characteristics: outsiders, independents, professionals, duality and size. With this set of hypothesis it 
is expected to find results similar to those of Rosenstein and Wyatt (1990), Silveira, Barros and Famá (2003), Arosa, Iturralde and Maseda (2010b), and Ramos and Olalla (2011), that the composition of the Board of Directors with a larger number of independent members, outsiders, positively influences the performance of the companies. This suggests that the higher the independence indicator of the Board, the greater the performance of the company. If endogeneity is proven, it is expected to find results similar to those of Prevost et al. (2002), that the relationship between the composition of the Board of Directors and performance has a positive and simultaneous interference.

\section{Board interlocking and performance of the companies}

A simple board interlock occurs when a person serves on the board of more than one company. Mutually interlocking relationships are defined to occur when at least two directors together serve on the boards of two different corporations. When a sense of direction to this mutuality can be identified, for example, the CEO of one company is serving on the board of a second company, while the CEO of that second company is also serving on the board of the first one; we define this as reciprocal interlocking (Fich \& White, 2005).

The interlocking of corporate directors is viewed as a cooperative strategy between economic organizations for reducing sources of uncertainty in their environments. Corporate interlocking is a means of anticipating or controlling sources of uncertainty stemming from potentially disruptive unilateral actions of other corporations (Allen, 1974).

Bezemer, Maassen, Van Den Bosch and Volberda (2007) explain that board interlocking can provide benefits to companies connected in a network, improving performance of organizations connected by sharing their directors. However, the relationships of the Board of Directors can compromise the independence of non-executive directors, generating conflicts of interest. A highly centralized and dense network of directors can create a social system in which the directors are loyal to each other and just act on interest.

Pombo and Gutiérrez (2011) found out a positive relationship between outsider directors, the degree of board interlocks and Return on Assets in Colombian companies. They also observed a positive relationship between outsider directors that are interconnected in other companies and performance of companies. So, the greater the interconnections among the external directors, the better the performance of the company. Kim (2005) studied the effects of the relationship and network of the Board of Directors on the performance of Korean companies and found out a positive association with the performance measured by ROA.

Santos and Silveira (2007) found out a negative relationship between board interlocking and the value of the company measured by Tobin's $Q$ in Brazilian companies. For Return on Equity (ROE) and Return on Assets (ROA), the result was more likely with a great level of interlocking. Under the focus of social networks, Mendes-da-Silva, Rossoni, Martin and Martelanc (2008), and Mendes-da-Silva (2011) found a positive relationship between board interlocking and the performance of the companies. Mendes-da-Silva et al. (2008) found a significant relationship among centrality, density, cohesion of companies and performance, both in terms of asset profitability, and in debt ratio. So, companies best positioned in corporate relationship networks tend to have higher profitability and lower debt. Mendesda-Silva (2011) also found a significant positive relationship between the board interlocking, measured by indicators of social networking, and performance.

Mizruchi (1996) points out five interlocking perspectives: (a) it is a way of co-option and / or monitoring of the companies; (b) it provides companies with information on business practices (Davis, 1996); (c) it reflects the cohesion of the directors (Useem, 2014); (d) it is the hypothesis of occupation; (e) it understands the Board Interlocking as a sociological phenomenon. The first two points of view indicate positive influence of interlocking on the performance of the company. In contrast, the hypothesis of occupation predicts negative influence on the performance of the company. Finally, the effect of the board interlocking can be positive, negative or neutral, when reflecting the cohesion of the directors (Non \& Franses, 2007) and, when reflecting sociological phenomenon can be, besides positive, 
negative (Labianca \& Brass, 2006). On the centrality, influential and prestigious directors participate in a greater number of the Board of Directors, and its centrality in the network measures its power and prestige (Mizruchi, 1996). Actors with more ties than other may have privileged positions, so a measure used as a proxy of a director's power in the social relations network is its centrality (Mendes-da-Silva, 2011). Thus, the third hypothesis was formulated:

H3: Board interlocking has positive influence on the performance of the companies.

With this hypothesis it is expected to be possible to state that the board interlocking influences positively the performance of the companies, which would indicate that the Board of Directors exercises its monitoring function. This perspective is based on the Agency Theory (Jensen \& Meckling, 1976), that the principal can make use of monitoring mechanisms, such as boards of directors, to mitigate the agency problem.

The rejection of this hypothesis indicates negative effects of social relations on performance, resulting from social ties maintained by the asymmetry of values and preferences of the network actors, making difficult maintenance of common goals (Labianca \& Brass, 2006). And due to differences of thought, values, patterns of behavior and cognition of the members involved in the network, which allow negative reciprocity. Thus, there would be the possibility of unsatisfactory results for the company (Mendes-da-Silva et al., 2008). Moreover, while the number of directorships appears to be closely linked to the directors' reputational capital, other studies suggest that too many directorships may lower the effectiveness of outside directors as corporate monitors (Fich \& Shivdasani, 2006). These results are similar to the studies of Santos, Silveira and Barros (2012), in Brazil, where the firm value is, on average, negatively impacted by interlocking directorships, especially in firms in which a majority of directors hold three or more board positions.

The set of hypothesis formulated in this study is based on the Agency Theory. So to investigate the relationship between the composition of the Board of Directors and the performance of the companies, it is considered that the Board is endogenously determined.

\section{Research Methodology}

For data collection a desk research was carried out, having as population the companies listed on BM\&FBovespa from 2007 to 2012, totaling 2,333 observations of 1,483 companies in the period, as shown in Table 1. Financial and insurance companies were excluded from the research due to the fact of their activities normally represent outliers in the performance indicators. Besides, they generally have bigger Board of Directors, especially composed by great clients and local companies' leaders. This criterion was also adopted by Shivdasani and Yermack (1999). It is also justified since in Brazil these companies have different systems regarding accrual basis (Lopes \& Tukamoto, 2007). The sample was calculated annually, stratified by segment, considering a margin of tolerable error of $5 \%$ and a critical value of 1.96 . 
Table 1

\section{Research Population}

\begin{tabular}{cccc}
\hline Year & Listed Companies & (-) Financial Companies & Studied Population \\
\hline 2012 & 718 & $(307)$ & 411 \\
2011 & 679 & $(281)$ & 398 \\
2010 & 657 & $(271)$ & 386 \\
2009 & 570 & $(193)$ & 377 \\
2008 & 682 & $(279)$ & 403 \\
2007 & 510 & $(152)$ & 358 \\
\hline Total of Observations & 3816 & $(1483)$ & 2333 \\
\hline
\end{tabular}

The outliers effect was analyzed for the dependent variables Tobin's Q and ROE, through the interquartile range criterion (IQR), also used by Gro $\beta$ (2007). The gap between the upper and lower quartiles was calculated (Fávero, Belfiore, Chan, \& Silva, 2009). This criterion allowed to identify 151 cases considered possible outliers, which were excluded from the sample. The IQR served as cut-off, reducing the sample size, and the data were not winsorized. Thus, the size of the final sample consisted of 1,163 cases. Table 2 represents the constructs of the research.

Table 2

\section{Research Constructs}

\begin{tabular}{|c|c|c|c|}
\hline Variables & Sub-variables & Metrics & Theoretical basis \\
\hline \multirow[t]{5}{*}{$\begin{array}{l}\text { Characteristics of } \\
\text { the Board of } \\
\text { Directors }\end{array}$} & Outsiders & $\begin{array}{l}\qquad \text { OUT }=\left(1-\frac{\mathrm{CEAC}}{\mathrm{TC}}\right) \\
\text { Where: } \mathrm{CEAC}=\text { Directors elected by } \\
\text { the Controlling Shareholder; } \mathrm{TC}= \\
\text { total of directors }\end{array}$ & $\begin{array}{l}\text { Lefort and Urzúa (2008), } \\
\text { preceded by Baysinger and Butler } \\
\text { (1985), Zahra and Pearce (1989), } \\
\text { Barnhart and Rosenstein (1998). }\end{array}$ \\
\hline & Independent & $\begin{array}{l}\qquad \text { Indep }=\frac{(\mathrm{DI})}{(\mathrm{TD})} \\
\text { Where: DI = number of independent } \\
\text { directors; TD }=\text { total number of } \\
\text { directors }\end{array}$ & $\begin{array}{l}\text { Lefort and Urzúa (2008), } \\
\text { preceded by Baysinger and Butler } \\
\text { (1985). }\end{array}$ \\
\hline & Professionals & $\begin{array}{l}\text { PROF }=\text { Indep }- \text { Out if Indep }>\text { Out } \\
\text { PROF }=\mathbf{0} \text { if Indep }<\text { Out. }\end{array}$ & $\begin{array}{l}\text { Lefort and Urzúa (2008), and } \\
\text { Bohman (2012). }\end{array}$ \\
\hline & Duality & $\begin{array}{l}\text { Duality }=\text { Belongs to the } \\
\text { Management of the company and the } \\
\text { Board of directors. In numbers. }\end{array}$ & $\begin{array}{l}\text { Ong and Wan (2001), preceded by } \\
\text { Chaganti, Mahajan and Sharma } \\
\text { (1985), Donaldson and Davis } \\
\text { (1991). }\end{array}$ \\
\hline & Size & $\begin{array}{l}\text { In of the Total members of the Board } \\
\text { of directors. }\end{array}$ & $\begin{array}{l}\text { Yermack (1996), Dwivedi and } \\
\text { Jain (2005), Cheng (2008), Arosa, } \\
\text { Iturralde and Maseda (2010a, } \\
\text { 2010b). }\end{array}$ \\
\hline
\end{tabular}


Table 2 (continued)

\begin{tabular}{|c|c|c|c|}
\hline Variables & Sub-variables & Metrics & Theoretical basis \\
\hline Board Interlocking & $\begin{array}{l}\text { Bonacich's } \\
\text { Centrality }\end{array}$ & $\begin{array}{l}\text { CB_B_Int }=\text { Bonacich's Centrality } \\
\text { for Board Interlocking } \\
\qquad C_{I}=\sum_{J}\left(\alpha+\beta C_{J}\right) x_{I J} \\
\text { Where: } x_{i j} \text { denotes each cell in the } \\
\text { corresponding relational matrix }\left(x_{i j}\right. \\
>0 \text { if the actors } i \text { and } j, i \neq j \text {, have ties } \\
\text { with each other, being } x_{i j}=0 \text { by } \\
\text { convention); } C_{j} \text { indicates the } \\
\text { centrality of other actors of the } \\
\text { network besides } i ; \alpha \text { and } \beta \text { are } \\
\text { parameters. }\end{array}$ & $\begin{array}{l}\text { Burt, (1983), Conyon and } \\
\text { Muldoom (2006), complemented } \\
\text { by Pombo and Gutiérrez (2011), } \\
\text { Kandel, Massa and Simonov } \\
\text { (2011), Mendes-da-Silva (2011), } \\
\text { Bohman (2012), and Fracassi and } \\
\text { Tate (2012). }\end{array}$ \\
\hline
\end{tabular}

In Brazil, good corporate governance practices establish that the Board of Directors have the following duties: the organization's decision-making process regarding to its strategic direction; the role of being the guardian of the principles, values, social object and the organization's governance system; for monitoring the board, acting as a link between it and the shareholders (Instituto Brasileiro de Governança Corporativa [IBGC], 2015).

For the calculation of the indicators (OUT; INDEP and PROF) this study used the description and the fundamentals of good corporate governance practices adopted in Brazil, which define the three categories of directors:

1. Internal - directors who occupy the position of executive officers or are employees of the organization;

2. External - directors with no current commercial contract of employment or in the direction of the organization, but they are not independent, as former directors and former employees, lawyers and consultants who provide services to the company, shareholders or employees of the controlling group, of its direct subsidiary, controlled by or in the same economic group and their close relatives and fund managers with significant participation;

3. Independent - outside directors who do not have family, business, or any other relationships with shareholders who have significant participation, controlling groups, executives, service providers and non-profit organizations that influence or may significantly influence the judgments, opinions, decisions and compromise the actions in the best interest of the organization.

It was used the model applied by Lefort and Urzúa (2008), preceded by Baysinger and Butter (1985), Hermalin and Weisbach (1988, 2003), and Barnhart and Rosenstein (1998), who analyzed the Board of Directors with simultaneous equations approach, with some adjustments in the control variables. Two independent variables were added, duality and board interlocking, and a dependent variable, ROE. Data collection was conducted in two parts: financial and market data; and data regarding the Board of Directors. The financial and market data were collected from Economática ${ }^{\circledR}$ database. The information on the Board of Directors were collected from BM\&FBovespa database and the Brazilian Securities Commission (CVM).

Interlock calculations were obtained from sociomatrixes of mxm order, with ties established between directors, according to the criteria used by Mendes-da-Silva (2011). For matrixes that reflected the board interlocking, it was necessary to develop a Java app, besides adopting manual and computational procedures for removing inconsistencies on name and CPF (Individual Taxpayer Registration Number with the Brazilian Federal Revenue Service) of directors, which resulted in 18,119 standardized observations regarding directors. For foreign directors a computational routine developed in Java was programmed, containing the characters of the names of each director, to assign sequential 
numbers equivalent to the CPF. After concluding the sequential numbering, the discrepancies of content in the spelling of the directors' name were analyzed.

The model contains a system with two simultaneous equations 3SLS, both for Tobin's Q and ROE, set from the endogeneity test. A model of simultaneous equations can be represented by Equations 1 and 2, as follows:

$$
\begin{aligned}
& \mathrm{X} \_\mathrm{t}=\alpha 0+\alpha 1+\mathrm{Y} \_\mathrm{t} \mathrm{U}_{-} 1 \mathrm{t} \\
& \mathrm{Y} \_\mathrm{t}=\beta 0+\beta 1+\beta 2 \mathrm{X} \_\mathrm{t} I \_\mathrm{t}+\mathrm{u} \_2 \mathrm{t}
\end{aligned}
$$

Since $\mathrm{X}$ depends on $\mathrm{Y}$ in the first equation and $\mathrm{Y}$ depends on $\mathrm{X}$ (and $\mathrm{I}$ ) in the second equation, $\mathrm{X}$ and $Y$, these are jointly determined, which defines a model of simultaneous equations. However, $\mathrm{X}$ and $\mathrm{Y}$ are endogenous variables, while $\mathrm{I}$ is exogenous or is determined out of the equation (Hill, Judge, \& Griffiths, 2010). In this study, $\mathrm{X}$ and $\mathrm{Y}$ comprised the variables: performance and composition of the Board of Directors. Equations 3 and 4 represent these models synthetically. After the endogeneity test these equations were dismembered, but we chose to not represent all models analytically.

$$
\begin{aligned}
& \mathrm{D}=\mathrm{CA}+\mathrm{BI}+\mathrm{VC} \\
& \mathrm{CA}=\mathrm{D}+\mathrm{BI}+\mathrm{VC}
\end{aligned}
$$

Where: $\mathrm{D}=$ performance; $\mathrm{CA}=$ the set of variables related to the composition of the Board of Directors; $\mathrm{BI}=$ board interlocking; $\mathrm{VC}=$ Control Variables.

After defining the general system, the endogeneity test was used to segregate each system by the composition of the Board of Directors, in order to test the hypotheses. To test the robustness of the model, endogenous tests were conducted according to the model of Gro $\beta$ (2007), using the criteria of Wu-Hausman F-test and Durbin-Wu-Hausman $\chi 2$ test (Chi-square), both for the Tobin's Q and for the ROE. The first stage (OLS) allowed to observe the matrix identification (Anderson canon and CraggDonald test, F-statistic Wald) and robustness of the tools (Anderson-Rubin test, Wald and Stock Wright test), which indicated that the matrix is identified and that the instruments are valid. The second stage (2SLS) allowed testing whether the regressor is exogenous by the criterion of Wu-Hausman F-test and Durbin-Wu-Hausman $\chi^{2}$ test (Chi-square). Both were conducted observing the efficiency and consistency of the estimates for homoscedasticity. The third stage (3SLS) allowed estimating the parameters in the systems of simultaneous equations.

\section{Description and Analysis of the Results}

\section{Descriptive statistics of the Board of Directors}

Table 3 presents the results of the descriptive statistics of the variables of the Board of Directors. These variables were calculated as indicated in the constructs of the research. For situations in which there were no comments it was stated zero, except for the size of the Board of Directors. 
Table 3

Descriptive Statistics of the Variables of the Board of Directors

\begin{tabular}{|c|c|c|c|c|c|c|c|c|}
\hline \multicolumn{9}{|l|}{ Panel A } \\
\hline \multicolumn{2}{|c|}{ Composition of the Board of Directors } & \multirow{2}{*}{$\frac{\mathbf{N}}{1163}$} & \multirow{2}{*}{\multicolumn{2}{|c|}{$\frac{\text { Min. }}{1,1}$}} & \multirow{2}{*}{$\frac{\text { Max. }}{4,41}$} & \multirow{2}{*}{$\begin{array}{c}\text { Average } \\
2,42\end{array}$} & \multirow{2}{*}{$\begin{array}{c}\text { S.D } \\
0,51\end{array}$} & \multirow{2}{*}{$\begin{array}{c}\text { Simet. } \\
-0,16\end{array}$} \\
\hline ln_TB & Size & & & & & & & \\
\hline INDEP & Independency & 1163 & & 0,12 & 1 & 0,57 & 0,15 & $-0,02$ \\
\hline OUT & Outsiders & 1163 & & 0 & 0,96 & 0,56 & 0,18 & $-0,16$ \\
\hline DUAL & Duality & 1163 & & 0 & 6 & 0,83 & 0,91 & 1,42 \\
\hline PROF & Professionals & 1163 & & 0 & 1 & 0,11 & 0,19 & 1,75 \\
\hline \multicolumn{9}{|l|}{ Panel B } \\
\hline \multicolumn{2}{|c|}{ Composition of the Board of Directors } & \multicolumn{2}{|l|}{$\mathbf{N}$} & \multirow{2}{*}{$\begin{array}{l}\text { Curt. } \\
-0,05\end{array}$} & \multirow{2}{*}{$\begin{array}{c}* \text { Toler. } \\
0,58\end{array}$} & \multirow{2}{*}{$\begin{array}{c}\text { *VIF } \\
1,73\end{array}$} & \multirow{2}{*}{$\begin{array}{c}* * \text { Toler. } \\
0,57\end{array}$} & \multirow{2}{*}{$\begin{array}{c}* * \mathbf{V I F} \\
1,74\end{array}$} \\
\hline $\ln \_\mathrm{TB}$ & Size & 1163 & & & & & & \\
\hline INDEP & Independency & 1163 & & $-0,27$ & 0,44 & 2,27 & 0,44 & 2,29 \\
\hline OUT & Outsiders & 1163 & & $-0,41$ & 0,31 & 3,24 & 0,31 & 3,26 \\
\hline DUAL & Duality & 1163 & & 3,39 & 0,97 & 1,03 & 0,97 & 1,03 \\
\hline PROF & Professionals & 1163 & & 2,31 & 0,21 & 4,86 & 0,20 & 4,90 \\
\hline \multicolumn{9}{|l|}{ Panel C } \\
\hline Variable & Description & $\mathbf{N}$ & Min. & Max. & Avergage & S.D & Simet. & Kurtosis \\
\hline Type 1 & $\begin{array}{l}\text { Member only of the } \\
\text { management }\end{array}$ & 1163 & 0 & 34 & 4,15 & 3,035 & 2,987 & 21,538 \\
\hline Type 2 & $\begin{array}{l}\text { Member only of the Board } \\
\text { of Directors }\end{array}$ & 1163 & 1 & 30 & 7,65 & 5,06 & 1,389 & 1,715 \\
\hline Type 3 & $\begin{array}{l}\text { Member of the management } \\
\text { and the Board of Directors }\end{array}$ & 1163 & 0 & 12 & 0,97 & 1,12 & 2,754 & 18,350 \\
\hline Size & $\begin{array}{l}\text { Size of the Board of } \\
\text { Directors }\end{array}$ & 1163 & 3 & 41 & 12,78 & 6,49 & 1,145 & 1,401 \\
\hline
\end{tabular}

Note. * Collinearity statistics - Tobin's Q; ** Collinearity statistics - ROE.

It is observed that the average size of the Board of Directors was 2.42 in logarithmic. This corresponds in natural numbers to an average size of 12 members. The maximum size was 4.4 with a pattern deviation of 0.51 , which in whole numbers corresponds to 41 directors. These results are consistent with the study made by Andrade, Salazar, Calegário and Silva (2009), who found an average of 10 members, with a pattern deviation of 5.46 for the year 2004, and to the study of Gondrige, Clemente and Espejo (2012), which found an average size of 11 members in Brazil. The results are also similar to those found by Shivdasani and Yermack (1999), who found an average size of 11 members for companies in the USA. However, these figures indicate that in Brazil the companies have relatively larger size of the Board of Directors as compared to an average of 6.6 found in New Zealand (Prevost, Rao, \& Hossain, 2002); 6.8 in Chile (Lefort \& Urzúa, 2008); and 7.13 in Colombia (Pombo \& Gutiérrez, 2011).

The sample studied indicates a trend in Brazil of companies exceeding the size recommended in the Brazilian corporate governance codes, which in 2002 recommended from five to nine members on the board and in 2015 from five to eleven members. According to Yermack (1996), smaller boards of directors are more effective and companies with this profile have more favorable values in financial performance. Lipton and Lorsch (1992) recommend limiting the board to 10 members, preferably with 
eight or nine members. Jensen (1993) stated that a board with more than seven or eight members is less likely to work effectively, and it is more likely to be controlled by the executive director.

Regarding the composition of the board of directors, outsiders and independence presented similar average ( 0.56 and 0.57$)$, with a pattern deviation of 0.18 and 0.15 , respectively. These numbers are similar to those reported by $\mathrm{Li}$ (1994) for European countries, and Prevost et al. (2002) for companies in New Zealand. These results are inferior to those found by Andrade et al. (2009), who found an average of $88 \%$, and Gondrige et al. (2012), who found an average of $71,49 \%$ for the Brazilian boards. However, these results are superior to those found by Lefort and Urzúa (2008) of 0.2 for both independent and outsiders in Chile. This indicates that in Brazil, despite having a larger size of the Board of Directors than that found by Lefort and Urzúa (2008) in Chile, members have greater independence and are more outsiders. This result can be explained by art. $143, \S 1^{\circ}$, of Law No. 6.404/76: "The members of the board, to a maximum of $1 / 3$ (one third), can be elected to the position of directors" (Lei n. 6.404, 1976, p. 108). Therefore, the board of directors, as a legal requirement, should be composed with the majority of external members.

On the theoretical basis, the Board of Directors, when characterized as independent, usually has a better reputation in the business community (Fama, 1980; Fama \& Jensen 1983a, 1983b; Jensen, 1993). Ong and Wan (2001) explained that a higher proportion of outsiders imply in optimization of the use of knowledge and skills, i.e., more professional members participating in the Board of Directors. For an administrative board to perform its main function, representing the owners before the executive board, it is appropriate to be essentially composed of people who do not belong simultaneously to the executive board, i.e., directors out of the executive board (Mendes-da-Silva \& Moraes, 2006).

The more independent the composition of the Board of Directors in terms of external directors, the lower the probability of the positions of CEO and chairman to be occupied by the same person (Andrade et al., 2009), represented in this study by the variable duality. An ideal board of directors must be constituted by mixing insiders and outsiders (Fama \& Jensen, 1983a). In the sample studied, using descriptive statistics, there is equity in the proportions between insiders and outsiders.

Regarding the duality of the Board of Directors, the average was 0.83 , with a pattern deviation of 0.91, consistent with the study of Pombo and Gutiérrez (2011), who found 0.91 with pattern deviation of 1.1 in Colombia. The Agency Theory indicates that the duality CEO/chairman is detrimental to the companies, once the same person has two roles. To minimize agency problems it is necessary to segregate the roles, to decide and to defend the interests of the owners. The duality CEO/chairman reduces the level of effort in the monitoring of patterns and controls. The more the companies practice the duality CEO/chairman, the lower the presence and use of knowledge and skills, and the greater the level of cohesion between the company and the $\mathrm{CEO} /$ chairman, however, the lower the effects of actions control, as the same person monitors, controls and decides (Ong \& Wan, 2001).

The average of professional members in the composition of the Board of Directors was 0.11 with a pattern deviation of 0.19 , similar to the study of Lefort and Urzúa (2008), who found an average of 0.1 and 0.1 of pattern deviation. The indicator that measures the professional directors reached 0.2 for tolerance, we chose to keep this indicator, since the theoretical framework indicates the need of the controlling owners to vote for professional directors in order to mitigate the agency problems and increase the value of the company (Lefort \& Urzúa, 2008).

The results of the symmetry coefficient indicate that the variable size of the Board of Directors, independence and outsiders tend to be negatively asymmetric; the others are positively asymmetric. The pattern deviation of the results indicates that the observations are homogeneous, except for size of the Board of Directors. 


\section{Endogeneity test of the composition of the Board of Directors with performance}

The hypothesis H1 was formulated to test the endogeneity between the composition of the Board and the performance of the companies. Table 4 presents the results of $\mathrm{Wu}-\mathrm{Hausman} \mathrm{F}$ test, and DurbinWu-Hausman $\chi 2$ test (Chi-square).

Table 4

Endogeneity Test

\begin{tabular}{|c|c|c|c|c|c|c|c|c|c|}
\hline \multirow{2}{*}{\multicolumn{2}{|c|}{$\begin{array}{l}\text { Characteristics of the } \\
\text { Board of Directors }\end{array}$}} & \multicolumn{4}{|c|}{ Tobin's Q } & \multicolumn{4}{|l|}{ ROE } \\
\hline & & & & p-value & Type & & & p-value & Type \\
\hline \multirow[t]{2}{*}{ INDEP } & \multirow[t]{2}{*}{ CA_Indep. } & 3,71 & $\mathrm{~F}(1,114)$ & $0,058^{*}$ & \multirow{2}{*}{ End. } & 6,65 & $\mathrm{~F}(1,114)$ & $0,01 *$ & \multirow{2}{*}{ End. } \\
\hline & & 3,77 & Chi-sq (1) & $0,058^{*}$ & & 6,72 & Chi-sq (1) & $0,00^{*}$ & \\
\hline \multirow[t]{2}{*}{ DUAL } & \multirow[t]{2}{*}{ Dual. of CA } & 0,1 & $F(1,114)$ & 0,75 & \multirow{2}{*}{ Exog. } & 14,81 & $F(1,114)$ & $0,00^{*}$ & \multirow{2}{*}{ End. } \\
\hline & & 0,1 & Chi-sq (1) & 0,74 & & 14,88 & Chi-sq (1) & $0,00^{*}$ & \\
\hline \multirow[t]{2}{*}{ PROF } & \multirow[t]{2}{*}{ CA_Prof. } & 17,99 & $\mathrm{~F}(1,114)$ & $0,00^{*}$ & \multirow{2}{*}{ End. } & 9,81 & $\mathrm{~F}(1,114)$ & $0,00^{*}$ & \multirow{2}{*}{ End. } \\
\hline & & 18,02 & Chi-sq (1) & $0,00^{*}$ & & 9,89 & Chi-sq (1) & $0,00^{*}$ & \\
\hline \multirow[t]{2}{*}{ OUT } & \multirow[t]{2}{*}{ CA_Out. } & 19,34 & $\mathrm{~F}(1,114)$ & $0,00^{*}$ & \multirow{2}{*}{ End. } & 0,87 & $\mathrm{~F}(1,115)$ & 0,34 & \multirow{2}{*}{ Exog. } \\
\hline & & 19,35 & Chi-sq (1) & $0,00^{*}$ & & 0,89 & Chi-sq (1) & 0,34 & \\
\hline
\end{tabular}

Note. Obs.: Statistical significance levels of: $* 1 \%, * * 5 \%$ and $* * * 10 \%$.

A p-value below $10 \%, p>0.1$, indicates the endogeneity of the Board of Directors with the performance of the companies. Therefore, with the exception of duality, all the characteristics of the Board of Directors are endogenous for Tobin's Q. For ROE, the exception was for outsiders.

Therefore, the results do not reject $\mathrm{H} 1$ regarding endogeneity and suggest the existence of dependency on the characteristics of the composition of the Board of Directors regarding performance. On the other hand, performance depends on the characteristics of the composition of the Board of Directors. Thus, there is a possibility that these variables are determined jointly by simultaneous equations. This resulted in a total of 12 equations for the model. However, due to the space, we chose to not replicate these equations:

$$
\begin{aligned}
& \text { Tobin's Q Q }=\beta_{0}+\beta_{1} \text { INDEP }_{i t}+\beta_{2} \text { DUAL }_{i t}+\beta_{3} \text { CB_B_int } \\
& \text { it }
\end{aligned}
$$

Where: $\mathrm{i}=$ represents the company, ranging from 1 to $\mathrm{N}, \mathrm{t}$ represents the year, ranging from 1 through T; Tobin's Q = market value (performance) can be replaced by the ROE; INDEP = characteristic of the composition of the Board of Directors independent (can be replaced by outsiders, professional); DUAL = characteristic of the composition of the Board of Directors duality (in ROE system, it is replaced by the feature outsiders); $C B \_B \_i n t=$ Board Interlocking; $\ln \_$TB $=$size of the Board of Directors; ln_AT = size of the company; ln_age = age of the company; SIC $=$ industry sector and anodummy $=$ time $; \mathrm{DC}=$ Control rights of the majority owner; $\mathrm{IDE}=$ excess rights; $\mathrm{PdcST}=$ control rights of the second and third owners; $\mathrm{u}_{\mathrm{it}}, \varepsilon_{\mathrm{it}},=$ are the terms of error of each equation.

The same systems of simultaneous equations were estimated for ROE. Due to space we chose to not replicate the equations, since they are identical to equations 5 and 6 . 
The board interlocking social network indicator was included in the model, but its reverse causality related to performance was not estimated due to lack of theoretical support. Size of the Board of Directors and Ownership Structure were analyzed along with the control variables, according to the model of Lefort and Urzúa (2008).

\section{Relationship of the composition of the Board of Directors with performance}

In Table 5, panels $\mathrm{A}$ and $\mathrm{B}$ show the results of the estimates of the composition of the Board of Directors with performance indicators, Tobin's Q for market value and ROE for return on equity, respectively, and the reverse causality of their characteristics.

Table 5

Composition of the Board of Directors on Companies' Performance

\begin{tabular}{|c|c|c|c|c|c|c|c|}
\hline \multicolumn{8}{|l|}{ Panel A } \\
\hline \multirow{2}{*}{ Description } & \multirow{2}{*}{ Acronyms } & Tobin's Q & INDEP & Tobin's Q & PROF & Tobin's Q & OUT \\
\hline & & MIV(1) & MIV(2) & $\operatorname{MIV}(3)$ & MIV(4) & $\operatorname{MIV}(5)$ & $\operatorname{MIV}(6)$ \\
\hline \multirow[t]{2}{*}{ Board Independent } & INDEP & 1,5498 & & - & - & & \\
\hline & & $-1,17$ & & & & & \\
\hline \multirow[t]{2}{*}{ Board duality } & DUAL & $-0,0057$ & & 0,0107 & & 0,0006 & \\
\hline & & $(-0,27)$ & - & $-0,51$ & - & $-0,02$ & - \\
\hline \multirow[t]{2}{*}{ Board Professional } & PROF & & & 1,2268 & & & \\
\hline & & & - & $-1,18$ & - & - & - \\
\hline \multirow[t]{2}{*}{ Board Outsiders } & OUT & & & & & $-2,6377$ & \\
\hline & & & & & 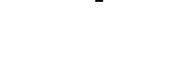 & $(-1,12)$ & \\
\hline \multirow[t]{2}{*}{ Board Interlocking } & CB_B_Int & 0,0003 & & 0,00008 & & 0,0001 & \\
\hline & & $-1,28$ & & $-0,43$ & & $-0,42$ & \\
\hline \multirow[t]{2}{*}{ Performance } & Tobin's Q & & $-0,2626$ & & $-0,3256$ & & 0,2676 \\
\hline & & & $(-1,75)^{* * *}$ & & $(-1,68)^{* * * *}$ & & $(1,59)^{* * *}$ \\
\hline \multirow[t]{2}{*}{ P. Majority Owner } & $\mathrm{DC}$ & $-0,2987$ & $-0,0897$ & $-0,3542$ & $-0,056$ & $-0,4725$ & 0,0266 \\
\hline & & $(-2,53)^{* *}$ & $(-2,05)^{* *}$ & $(-2,9)^{*}$ & $(-0,99)$ & $(-2,47)^{* *}$ & $-0,54$ \\
\hline \multirow[t]{2}{*}{ Excess rights } & IDE & $-0,0572$ & & $-0,0581$ & & $-0,0384$ & \\
\hline & & $(-1,58)$ & - & $(-1,6)^{* * *}$ & - & $(-0,83)$ & - \\
\hline \multirow{2}{*}{$\begin{array}{l}\text { P. second and third } \\
\text { owners }\end{array}$} & PdcST & $-0,4758$ & & $-0,4537$ & & $-0,5822$ & \\
\hline & & $(-2,35)^{* *}$ & - & $(-2,33)^{* *}$ & - & $(-2,08)^{* * *}$ & - \\
\hline \multirow[t]{2}{*}{$\begin{array}{l}\text { Size of the board of } \\
\text { directors } * * * *\end{array}$} & ТВ & 1,15 & 1,16 & 1,17 & 1,19 & 1,25 & 0,92 \\
\hline & & $-1,15$ & $(3,45)^{*}$ & $-1,49$ & $(3,11)^{*}$ & $(3,07)^{*}$ & $(-1,75)^{* * *}$ \\
\hline \multirow{2}{*}{$\begin{array}{l}\text { Size of the } \\
\text { Company } * * * *\end{array}$} & AT & 0,9316 & 0,981 & 0,936 & 0,973 & 0,9218 & 1,0157 \\
\hline & & $(-4,3)^{*}$ & $(-1,67) * * *$ & $(-3,98) *$ & $(-1,85)^{* * * *}$ & $(-3,85)^{*}$ & 1,21 \\
\hline
\end{tabular}


Table 5 (continued)

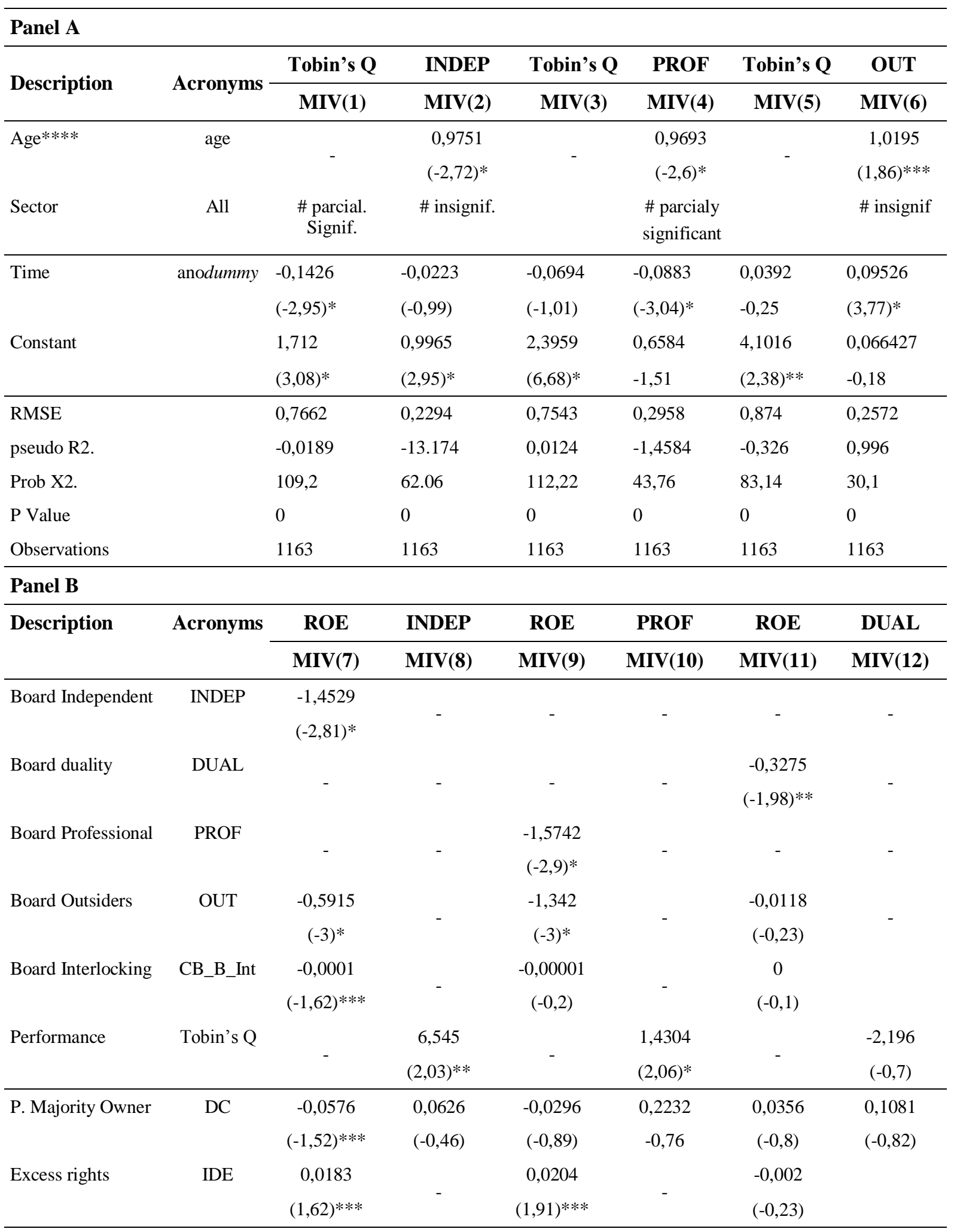


Table 5 (continued)

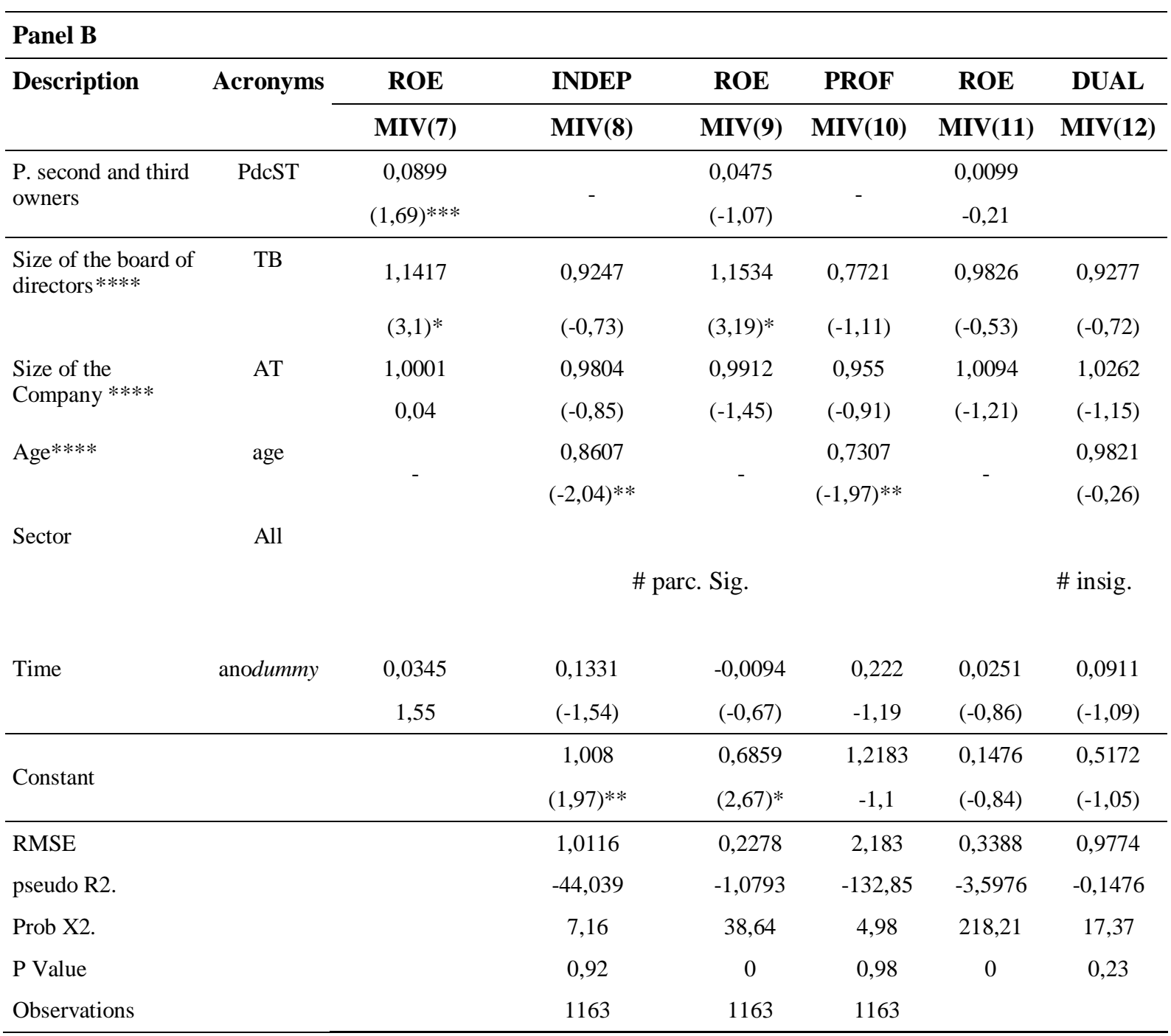

Note. Numbers in parentheses refer to the statistical z. Statistical significance levels of: *1\%,** 5\% and *** 10\%. \# will not be detailed due to the space. $* * * *$ The original values of the variable were calculated in all constant of the natural logarithm (ln).

In the analysis, $p$-value is considered lower or equal to 0.1 , which indicates statistical significance. Analyzing the coefficients, the effects of (+ or -) are observed. In general, the adjustments of MI model are at the expected level, with a p-value below 0.01 and RMSE between 0 and 1 , with the exception of the systems which estimate the reverse causality for ROE, columns MI8 and MI10, having RMSE above 1. As p-value was 0.00 , so, generally, the model is statistically significant.

The results show that the effects of the composition of the Board of Directors, measured by the characteristics (independence, professional, outsiders, duality) and by the board interlocking in Tobin's Q, Panel A, are not statistically significant at a p-value of 0.1 , as columns $\mathrm{MI}(1) \mathrm{MI}(3)$ and $\mathrm{MI}(5)$. However, for ROE, Panel B, the results indicate statistical significance at a p-value of 0.1 , as columns $\operatorname{MI}(7), \operatorname{MI}(9)$ and $\operatorname{MI}(11)$, with the exception of board interlocking in systems MI(9) and MI(11) and outsiders in the system MI(11). These results reject the hypothesis $\mathrm{H} 2$, which provides positive effects of the characteristics of the Board of Directors on the performance of the companies once the characteristics of the Board of Directors promote the alignment of interests for Tobin's Q and do not fully reject for ROE.

When evaluating the statistical significance in relation to the market value, Panel A, the results corroborate the argument of natural selection (Alchian, 1950; Demsetz \& Lehn, 1985; Friedman, 1953), 
for market value. For ROE, the effects were negative in all systems. The results of Panel A and Panel B are contradictory to Rosenstein and Wyatt (1990), Arosa et al. (2010b), and Ramos and Olalla (2011), who observed that the composition of the Board of Directors resulted in positive changes in performance. For ROE, Panel B, they are similar to Agrawal and Knoeber (1996) and in Brazil to Santos and Silveira (2007) and Santos et al. (2012), who found that the composition of Board of Directors resulted in negative changes in the performance of the companies.

Regarding the influence of independence and professionalism of the Board of Directors on ROE, Panel B, columns MI(7), MI(9) and MI(11), the results are supported by the Agency Theory arguments, stated by Fama and Jensen (1983a), that in the absence of the effect monitoring interests, there may be a negative effect on the performance. Once there are agency costs due to the reduction in the assets managed by managers not monitored.

One justification for this evidence could be related to the Brazilian regulation. Another is that independent directors fail to improve the internal results of the company, therefore, are not effective on the return on invested capital (ROE). Finally, it is justified due to failures in the development of the activities: (a) CEO entrenchment prevention; (b) increase the effectiveness of monitoring of the Board of Directors; (c) availability of the Board of Directors to advise the CEO (Fama \& Jensen, 1983a; Rechner \& Dalton, 1991). This theoretical justification may also explain the results related to the professional characteristic.

Regarding the duality, Zahra and Pearce (1989) explain that its occurrence is detrimental to the companies, once the same person compromise its independence, validating its own examinations of documentation, a fact observed in Panel B for ROE, column MI(11).

The results for the board interlocking are significant only in the system $\operatorname{IM}(7)$ at a p-value $<0.1$, however, the parameter estimates were low. According to the results of parameter estimation, there is practically no effect of social relations between members of the Board of Directors on the performance of the companies in the sample. Thus, the theoretical hypothesis H3 is rejected: Board interlocking has positive influence on the performance of the companies. Parameter estimates are practically null, thus, the statistical evidence are strongly indicating the occurrence of natural selection, as proposed by Alchian (1950) and Friedman (1953). However, previous studies included in this article did not present such evidence. Therefore, it may indicate that the widely accepted view that the modern corporation is an independent and self-sufficient organ ruled by its own self-perpetuating management needs to be modified on several points (Dooley, 1969).

Chahine and Goergen (2013) state that board interlocking produces harmful effects by increasing the dependency of the management and, thus, compromise the monitoring role for which is designated. Another factor focuses on the arguments of Labianca and Brass (2006) and Mendes-da-Silva et al. (2008), on the negative social relationships, which may have a negative effect on the performance of the companies. According to these authors, some negative social relationships may provide greater power than positive, impacting on the performance of the companies to a point of decreasing the market value of the companies.

As for reverse causality, i.e., the probability of performance influencing the composition of the Board of Directors, as specified in columns MI(8), MI(10) and MI(12), for ROE it was found out to be significant and positive for independence and professional constructs at a p-value $<0.1$; and insignificant and negative at a p-value $<10 \%$ for duality. Regarding Tobin's Q, as columns MI(2), MI(4) and MI (6), it was found out that the market value is significant and positive for outsiders - OUT variable at a pvalue $<0,1$. And significantly negative at a $\mathrm{p}$-value $<0.1$ for two variables: independence - INDEP variable, and participation of professional directors - PROF variable.

For the outsider members of the Board of Directors, the positive results indicate the interest of the monitoring and advisory mechanism, i.e., companies with higher market values, in this study measured by Tobin's Q, tend to have more external members on their Board of Directors. Therefore, companies that stand out regarding the market value tend to have more outsider directors. The literature 
states that outsider directors are able to establish viable links with the various sectors of the external environment, due to their technical expertise, offering advice to management (Zahra \& Pearce, 1989). Outsiders provide essential resources for the company (Pfeffer \& Salancik, 1978). Thus, companies with better indicators in Tobin's $Q$ use the benefits of keeping outsiders directors. However, for the characteristics of independence and professionalism the results are the opposite.

Evidences suggest that the market value may affect the characteristics of the composition of the Board of Directors, but not vice-versa. These results are similar to the study of Lefort and Urzúa (2008), who found the reverse causality of performance in the characteristics of the Board of directors.

Comparing the results obtained for ROE with Tobin's Q results, it was found out that this indicator tends to be more unstable when compared to Tobin's Q, due to the financial data, based on the results of the company (profit/loss), being annual and influenced by the past. According to Demsetz and Lehn (1985), accounting earnings may reflect fluctuations year by year better than the market data.

To evaluate the effect of the control variables in the study, the model of Lefort and Urzúa (2008) was used. Therefore, the analysis was divided into: characteristics of the companies, size of the Board of Directors, size of the company, time (as measured by the survey period), sector and Ownership Structure.

The results show that the effects of the characteristics of the companies are significant at a p-value of 0.1 in relation to Tobin's Q, for the following characteristics: size of the Board of Directors for outsiders model (MI-5); size of the company and sector for all models; time for the independent model (MI-1). All constants for the systems observed Tobin's Q as the dependent variable were statistically significant.

The size of the Board of Directors was statistically significant and positive in the market value, for the system that considers outsiders as endogenous variable. This result differs from what was stated by Yermack (1996), and Barnhart and Rosenstein (1998), that companies with smaller Board of Directors (in a determined proportion of outsider directors) tend to be more efficient than those with larger Board of Directors. In this study, the larger the size of the Board of Directors of the companies in the sample, the higher Tobin's Q. These results are justified and aligned with the arguments of Arosa et $a l$. (2010b) that the number of directors may influence the monitoring and control activity exercised by the Board of Directors. Considering that the monitoring capacity increases as more directors are added, the benefits may be offset by the cost of communication and decision-making associated with larger groups.

Regarding the size of the company, the results indicated a statistically significant positive effect on the market value of the sample, for all systems. This result is aligned with the statements of Warokka (2008), that the size of the company affects the company's management policy and, therefore, the performance, since larger companies tend to keep their internal controls aligned with their needs. As large companies are more diversified, they tend to be more susceptible to a better performance. However, for profitability, the research results were not statistically significant.

Regarding the time, the results indicated that when the independence of the Board of directors is considered in the model, the time had a negative effect. This can be explained by the fact that in the period analyzed Tobin's Q reduced. The time dummy captures not observed effects, which in this case may be related to the economic crisis and the reduction of capital market performance. The construct age was statistically insignificant, similar to what was observed by Barnhart and Rosenstein (1998), and Lefort and Urzúa (2008).

Regarding the construct sector, all models showed partial statistical significance, with a negative effect for Tobin's Q, i.e., some sectors had statistically significant negative effects on the market value of the companies. The following sectors showed negative effect on Tobin's Q: industrial goods (MVI1 and MVI-3); and telecommunications and information technology (MVI-1; MVI-3, and MVI-5). 
For the concentration of the Ownership Structure, all models related to Tobin's Q and for the independence of the Board of Directors had statistically significant negative effects, i.e., the concentrated Ownership Structure negatively determines the performance of the companies and the independence of the Board. The control rights of the majority owner (DC) have negative effects on ROE. These results are aligned with those of Ghosh and Sirmans (2003), in relation to the institutional ownership or block ownership, which did not succeed in regulating the monitoring mechanism of the outsiders directors, although their presence have improved the performance. These results are divergent from Lefort and Urzúa (2008).

The dispersed ownership measured by the control rights of the second and third largest owners was positive for ROE, indicating effect of interest alignment. For IDE, indicator of excess of rights, the results are statistically significant with negative effect in relation to Tobin's $Q$ in the system that considers the Board of Directors professionals. And the results were statistically significant with positive effect for ROE in the system that considers the members of the Board of Directors independent and professionals, as opposed to the findings related to Tobin's Q. This divergence can be explained by the handling arguments (Rossoni, 2009) and the instability of the financial indicators (Demsetz \& Lehn, 1985).

The results indicate that the effects of the characteristics of the companies are significant at a pvalue of 0.1 in relation to ROE for the following characteristics: size of the Board of Directors in the independence (MI-7) and professional (MI-9) models; and sector, for all models was partially significant. It is noteworthy that the size of the company, the age and the time are statistically insignificant for all models in the composition of the Board of Directors in relation to ROE.

The size of the Board was statistically significant positive for ROE for the system that considers the independence of the Board of Directors and professional members as endogenous variable. That is, the larger the Board, the higher the ROE, which differs from the results of Yermack (1996), and Barnhart and Rosenstein (1998). These results are similar to those found in this study for the size of the Board of Directors and market value, determined by Tobin's Q. Therefore, the arguments are similar, so they are not replicated. It is noteworthy that Tobin's $Q$ is a performance indicator that reflects the intangible assets of the company, according to Hermalin and Weisbach (2003), and ROE reflects the internal performance.

Regarding the variable sector, all the applied models showed partial statistical significance, with a positive effect for ROE. It is noteworthy that some sectors have produced statistically significant positive effects on the profitability of the sample, but not all.

The model that was more effective to capture the effects of the sectoral dummy is the one that considers the effects of professionals in the Board of Directors. The following sectors had a positive effect on ROE: cyclical consumption, (MI-7 and MI-9); non- cyclical consumption and telecommunications (MI-9); public utility, all models; and information technology (professionals - MI9). These results are similar to those found in this study, in relation to the market value, calculated through Tobin's Q. Therefore, the arguments used are similar, so they are not replicated.

\section{Conclusions}

The objective of this study was to verify, from the perspective of Agency Theory, the influence of the composition of the Board of Directors and its social relations (board interlocking) on the performance of Brazilian companies. Regarding the composition of the Board of Directors, a possible duality on the segregation of roles was observed. The literature indicates that the segregation of roles and duties will lead to: (a) CEO's entrenchment evasion; (b) increase in monitoring efficiency; (c) availability of the President of the Board of Directors to inform the CEO; (d) establishment of the 
independence of the Board of Directors and the management (Fama \& Jensen, 1983a; Rechner \& Dalton, 1991).

The Agency Theory indicates that the duality CEO/chairman is detrimental to the companies, once the same person accumulates two roles, which reduces the level of effort in the implementation and monitoring of standards and controls. The more the companies practice the duality $\mathrm{CEO} / \mathrm{chairman}$, the lower the presence and use of knowledge and skills, and the greater the level of cohesion between the company and the CEO/chairman, but the less the effects of controlling actions, as the same person monitors, controls and decides (Ong \& Wan, 2001).

Regarding outsiders and independent directors, the study indicated that, although there was a duality in the role of the directors, they are independent and external. This can be justified by the fact that Law n. 6.404/76, art. 143, $\S 1^{\circ}$, provides that the majority of the Board of Directors should be composed of external members (Lei n. 6.404, 1976).

According to the theoretical framework (Fama, 1980; Fama \& Jensen, 1983a, 1983b; Jensen, 1993), when the Board of Directors is characterized as independent, it tends to have better reputation. Ong and Wan (2001) explain that a higher proportion of outsiders implies optimization of the use of knowledge and skills, i.e., more professional members participating in the Board of Directors. Fama and Jensen (1983a) show that an ideal Board of Directors should be composed by a mixture of insiders and outsiders. In this study, the results showed equity in the proportions of insiders and outsiders.

About the influence of the composition of the Board of Directors on the performance of the companies, it was found out that among the variables used to identify its characteristics, some showed endogeneity. These results indicate simultaneous effects in the directions of these variables and reverse causality in the relationship between performance and the characteristics of the Board of Directors, consistent with the results of Prevost et al. (2002), Lefort and Urzúa (2008), and Turki and Sedrine (2012).

Among the characteristics of the Board of Directors, the duality of the board was exogenous for Tobin's Q and the outsiders were exogenous for ROE. Thus, the duality of the board is more influenced by the specificities of each company than by the market value of the companies. Regarding the characteristic outsiders, it is more influenced by the institutional environment than by the ROE, once through the analysis of the descriptive statistics, it was observed that the number of outsider members is aligned with the parameter set by the Brazilian legislation.

As for the effect of the different characteristics of the Board of Directors on the performance of the companies, it was found out, in relation to Tobin's Q, that all variables were statistically insignificant. Thus, there is no empirical evidence that the composition of the Board of Directors has positive influence on the market value of the companies, therefore, hypothesis $\mathrm{H} 2$ is rejected. These results are aligned with the studies of Chaganti et al. (1985) and Ong (1999).

From the perspective of the Agency Theory, it is possible to state that these results are supported by the arguments of natural selection. Another conclusion focuses on the effects of the regulation and institutional environment, since the Brazilian law establishes that the maximum of $1 / 3$ of the Board members can be composed of directors of the company. Therefore, the characteristics of the Board in Brazil are determined via institutional environment and not for the purpose of maximizing the market value of companies.

Similarly to the results obtained for the characteristics of the Board of Directors, the practice of board interlocking proved to be insignificant in relation to the market value, indicating natural selection. So, hypothesis $\mathrm{H} 3$ is rejected. These results contradict previous studies that found statistically significant effects of board interlocking on market value (Chahine \& Georgen, 2013). Therefore, it is not possible to infer that the board interlocking can increase the dependency of the management, compromising the role of monitoring, and it is also not possible to state that it can reduce the conflict of interest and the agency costs. 
The regression results of the systems of equations, whose dependent variable is profitability, indicated negative effect for all the characteristics of the Board of Directors. So, hypothesis H3 is rejected. These results are aligned with the studies of Agrawal and Knoeber (1996), and Santos and Silveira (2007). According to the Agency Theory, advocated by Fama and Jensen (1983a), in the absence of the effect of monitoring interest the effect of entrenchment can occur. Thus, when the independence of the Board of Directors is compromised and there are evidences of members' duality compromising the segregation of roles, there is a reduction in the managed assets and the agency costs are observed.

In addition, independent directors cannot improve the internal performance of the company, therefore, they are not effective in relation to the return on invested capital. Regarding the board interlocking, all estimates were null. Thus, the statistical evidence strongly indicates the occurrence of natural selection. The differences in the results of this research in relation to previous studies can be an interesting motivation for future research in order to find possible explanations.

Based on the survey results, it is possible to conclude that in the investigated Brazilian companies the economic aspects outweigh the sociological ones on performance, despite the fact that the Agency Theory states that the individual characteristic of REMM is of a rational being, which maximizes its self-interest (Jensen \& Meckling, 1976). However, Meckling (1976) had already stated in his seminal study that the individual, besides being economic, is sociological, psychological and political. The research contributed for instigating more research on the utility functions of the Board of Directors, consisting not only of monetary aspects, but also of factors such as regulation, power, prestige and career prospects.

\section{References}

Agrawal, A., \& Knoeber, C. R. (1996). Firm performance and mechanisms to control agency problems between managers and shareholders. Journal of Financial and Quantitative Analysis, 31(3), 377397. doi: $10.2307 / 2331397$

Alchian, A. A. (1950). Uncertainty, evolution, and economic theory. Journal of Political Economy, 58(3), 211-221. doi: 10.1086/256940

Allen, M. P. (1974). The structure of interorganizational elite cooptation: interlocking corporate directorates. American Sociological Review, 39(3), 393-406. doi: 10.2307/2094297

Andrade, L. P., Salazar, G. T., Calegário, C. L. L., \& Silva, S. S. (2009). Governança corporativa: uma análise da relação do conselho de administração com o valor de mercado e desempenho das empresas brasileiras. Revista de Administração Mackenzie, 10(4), 4-31. doi: 10.1590/S167869712009000400002

Arosa, B., Iturralde, T., \& Maseda, A. (2010b). Outsiders on the board of directors and firm performance: evidence from Spanish non-listed family firms. Journal of Family Business Strategy, 1(4), 236-245. doi: 10.1016/j.jfbs.2010.10.004

Arosa, B., Iturralde, T., \& Maseda, A. (2010a). Ownership structure and firm performance in non-listed firms: evidence from Spain. Journal of Family Business Strategy, 1(2), 88-96. doi: 10.1016/j.jfbs.2010.03.001

Barnhart, S. W., \& Rosenstein, S. (1998). Board composition, managerial ownership, and firm performance: an empirical analysis. Financial Review, 33(4), 1-16. doi: 10.1111/j.15406288.1998.tb01393.x

Barro, J. R., \& Barro, R. J. (1990). Pay, performance, and turnover of bank CEOs [Working Paper N $^{\circ}$ 3262]. National Bureau of Economic Research, Cambridge, MA, USA. doi: 10.3386/w3262 
Baysinger, B. D., \& Butler, H. N. (1985). Corporate governance and the board of directors: performance effects of changes in board composition. Journal of Law, Economics, \& Organizations, 1(1), 101124.

Bezemer, P.-J., Maassen, G. F., Van Den Bosch, F. A. J., \& Volberda, H. W. (2007). Investigating the development of the internal and external service tasks of non-executive directors: the case of the Netherlands (1997-2005). Corporate Governance: An International Review, 15(6), 1119-1129. doi: $10.1111 / \mathrm{j} .1467-8683.2007 .00635 . x$

Bhagat, S., \& Black, B. (1999). The uncertain relationship between board composition and firm performance. The Business Lawyer, 54(3), 921-963.

Black, B. S., Jang, H., \& Kim, W. (2006). Does corporate governance predict firms' market values? Evidence from Korea. Journal of Law, Economics, and Organization, 22(2), 366-413. doi: 10.1093/jleo/ewj018

Bohman, L. (2012). Bringing the owners back in: an analysis of a 3-mode interlock network. Social Networks, 34(2), 275-287. doi: 10.1016/j.socnet.2012.01.005

Burt, R. S. (1983). Firms, directors and time in the directorate tie market. Social Networks, 5(1), 13-49. doi: 10.1016/0378-8733(83)90014-X.

Caswell, J. A. (1984). An institutional perspective on corporate control and the network of interlocking directorates. Journal of Economic, 18(2), 619-626. doi: 10.1080/00213624.1984.11504262

Chaganti, R. S., Mahajan, V., \& Sharma, S. (1985). Corporate board size, composition and corporate failures in retailing industry. Journal of Management Studies, 22(4), 400-416. doi: 10.1111/j.1467-6486.1985.tb00005.x

Chahine, S., \& Goergen, M. (2013). The effects of management-board ties on IPO performance. Journal of Corporate Finance, 21(3), 153-179. doi: 10.2139/ssrn.2200362

Cheng, S. (2008). Board size and the variability of corporate performance. Journal of Financial Economics, 87(1), 157-176. doi: 10.1016/j.jfineco.2006.10.006

Cho, M.-H. (1998). Ownership structure, investment, and the corporate value: an empirical analysis. Journal of Financial Economics, 47(1), 103-121.

Conyon, M. J., \& Muldoon, M. R. (2006). The small world of corporate boards. Journal of Business Finance \& Accounting, 33(9-10), 1321-1343. doi: 10.1111/j.1468-5957.2006.00634.x.

Davis, G. F. (1996). The significance of board interlocks for corporate governance. Corporate Governance: An International Review, 4(3), 154-159. doi: 10.1111/j.1467-8683.1996.tb00144.x

Demsetz, H., \& Lehn, K. (1985). The structure of corporate ownership: causes and consequences. Journal of Political Economy, 93(6), 1155-1177. doi: 10.1086/261354

Donaldson, L., \& Davis, J. H. (1991). Agency theory or stewardship theory: CEO governance and shareholder returns. Australian Journal of Management, 16(1), 49-64.

Dooley, P. C. (1969). The interlocking directorate. The American Economic Review, 59(3), 314-323.

Dwivedi, N., \& Jain, A. K. (2005). Corporate governance and performance of Indian firms: the effect of board size and ownership. Employee Responsibilities and Rights Journal, 17(3), 161-172. doi: 10.1007/s10672-005-6939-5.

Fama, E. F. (1980). Agency problems and the theory of the firm. Journal of Political Economy, 88(2), 288-307. doi: 10.1086/260866 
Fama, E. F., \& Jensen, M. C. (1983b). Agency problems and residual claims. Journal of Law and Economics, 26(2), 327-349. doi: 10.2139/ssrn.94032

Fama, E. F., \& Jensen, M. C. (1983a). Separation of ownership and control. Journal of Law and Economics, 26(2), 301-325. doi: 10.1086/467037

Fávero, L. P., Belfiore, P. P., Chan, B. L., \& Silva, F. L. (2009). Análise de dados: modelagem multivariada para tomada de decisões. Rio de Janeiro: Elsevier, Campus.

Fich, E. M., \& Shivdasani, A. (2006). Are busy boards effective monitors? The Journal of Finance, 61(2), 689-724. doi: 10.1111/j.1540-6261.2006.00852.x

Fich, E. M., \& White, L. J. (2005). Why do CEOs reciprocally sit on each other's boards?. Journal of Corporate Finance, 11(1/2), 175-195. doi: 10.1016/j.jcorpfin.2003.06.002

Fracassi, C., \& Tate, G. (2012). External networking and internal firm governance. The Journal of Finance, 67(1), 153-194. doi: 10.1111/j.1540-6261.2011.01706.x

Friedman, M. (1953). Part I - The methodology of positive economics. In M. Friedman, Essays in positive economics (pp. 145-178). Chicago: University of Chicago Press.

Ghosh, C., \& Sirmans, C. F. (2003). Board independence, ownership structure and performance: evidence from real estate investment trusts. The Journal of Real Estate Finance and Economics, 26(2/3), 287-318. doi: 10.1023/A:1022932326610

Gondrige, E. O., Clemente, A., \& Espejo, M. M. S. B. (2012). Composition of the board and firm value of Brazilian public companies. Brazilian Business Review, 9(3), 72-95. Retrieved from http://www.bbronline.com.br/public/edicoes/9_3/artigos/clanksc2jj1432016155120.pdf. doi: 10.15728/bbr.2012.9.3.4

Granovetter, M. (1994). Les institutions économiques comme construction sociales: un cadre d'analyse. In A. Orléans (Org.), Analyse économique des conventions (pp. 79-94). Paris: PUF.

Groß, K. (2007). Equity ownership and performance: an empirical study of German traded companies. Heidelberg: Physica-Verlag Heidelberg. doi: 10.1007/978-3-7908-1934-2

Hermalin, B. E., \& Weisbach, M. S. (1988). The determinants of board composition. The Rand Journal of Economics, 19(4), 589-606.

Hermalin, B. E., \& Weisbach, M. S. (2003). Boards of directors as an endogenously determined institution: a survey of the economic literature. Economic Policy Review, 9(1), 7-26. doi: 10.2469/dig.v34.n1.1410

Hill, R. C., Judge, G. G., \& Griffiths, W. E. (2010). Econometria; heterocedasticidade; probabilidade - conceitos básicos; regressão linear simples. São Paulo: Saraiva.

Instituto Brasileiro de Governança Corporativa. (2015). Código das melhores práticas de governança $\begin{array}{llll}\text { corporativa (5a } & \text { ed.). São Paulo: IBGC. Retrieved from }\end{array}$ http://www.ibgc.org.br/userfiles/2014/files/codigoMP_5edicao_web.pdf

Jensen, M. C. (1993). The modern industrial revolution, exit, and the failure of internal control systems. The Journal of Finance, 48(3), 831-880. doi: 10.1111/j.1540-6261.1993.tb04022.x

Jensen, M. C., \& Meckling, W. H. (1976). Theory of the firm: managerial behavior, agency costs and ownership structure. Journal of Financial Economics, 3(4), 305-360. doi: 10.1016/0304$405 X(76) 90026-X$ 
Kandel, E., Massa, M., \& Simonov, A. (2011). Do small shareholders count? Journal of Financial Economics, 101(3), 641-665. doi: 10.1016/j.jfineco.2011.03.018

Kim, Y. (2005). Board network characteristics and firm performance in Korea. Corporate Governance: An International Review, 13(6), 800-808. doi: 10.1111/j.1467-8683.2005.00471.x

Klein, H. K., \& Myers, M. D. (1999). A set of principles for conducting and evaluating interpretive field studies in information systems. MIS Quarterly, 23(1), 67-93. doi: 10.2307/249410

Kosnik, R. D. (1987). Greenmail: a study of board performance in corporate governance. Administrative Science Quarterly, 32(2), 163-185. doi: 10.2307/2393124

Labianca, G., \& Brass, D. J. (2006). Exploring the social ledger: negative relationships and negative asymmetry in social networks in organizations. Academy of Management Review, 31(3), 596-614. doi: 10.5465/AMR.2006.21318920

Lefort, F., \& Urzúa, F. (2008). Board independence, firm performance and ownership concentration: evidence from Chile. Journal of Business Research, 61(1), 615-622. doi: 10.1016/j.jbusres.2007.06.036

Lei n. 6.404, de 15 de dezembro de 1976. (1976). Dispõe sobre as sociedades por ações. Diário Oficial da União. Brasília, DF: Presidência da República.

Lipton, M., \& Lorsch, J. W. (1992). A modest proposal for improved corporate governance. The Business Lawyer, 48(1), 59-77.

Lopes, A. B., \& Tukamoto, Y. S. (2007). Contribuição ao estudo do gerenciamento de resultados: uma comparação entre as companhias abertas brasileiras emissoras de ADRs e não-emissoras de ADRs. Revista de Administração, 42(1), 86-96. Retrieved from http://www.revistas.usp.br/rausp/article/view/44427. doi: 10.1590/S0080-21072007000100008

Martins, O. S., Mazer, L. P., Lustosa, P. R. B., \& Paulo, E. (2012). Características e competências dos conselhos de administração de bancos brasileiros e sua relação com seu desempenho financeiro. Revista Universo Contábil, 8(3), 24-39. Retrieved from http://proxy.furb.br/ojs/index.php/universocontabil/article/view/2483/2028. doi: 10.4270/RUC.2012321

Meckling, W. H. (1976). Values and the choice of the model of the individual in the social sciences. Swiss Journal of Economics and Statistics, 112(4), 545-560.

Mendes-da-Silva, W. (2011). Small worlds and board interlocking in Brasil: a longitudinal study of corporate networks, 1997-2007. Brazilian Review of Finance, 9(4), 521-548. Retrieved from http://bibliotecadigital.fgv.br/ojs/index.php/rbfin/article/view/3176/2389

Mendes-da-Silva, W., \& Moraes, W. F. A. (2006). Punidos por baixo desempenho: impactos da governança corporativa sobre o turnover de executivos no Brasil. Organizações \& Sociedade, 13(36), 125-143. doi: 10.1590/S1984-92302006000100007

Mendes-da-Silva, W., Rossoni, L., Martin, D. M. L., \& Martelanc, R. (2008). A influência das redes de relações corporativas no desempenho das empresas do novo mercado da Bovespa. Revista Brasileira de Finanças, 6(3), 337-358. Retrieved from http://bibliotecadigital.fgv.br/ojs/index.php/rbfin/article/view/1344/697

Mizruchi, M. S. (1996). What do interlocks do? An analysis, critique, and assessment of research on interlocking directorates. Annual Review of Sociology, 22(1), 271-298. doi: 10.1146/annurev.soc.22.1.271 
Mizruchi, M. S. (2004). Berle and Means revisited: the governance and power of large U.S. corporations. Theory and Society, 33(5), 579-617. doi: 10.1023/B:RYSO.0000045757.93910.ed

Non, M., \& Franses, P. H. (2007). Interlocking boards and firm performance: evidence from a new panel database [Tinbergen Institute Discussion Paper TI 2007-034/2]. Tinbergen Institute, Erasmus Universiteit, Universiteit van Amsterdam, Vrije Universiteit Amsterdam, The Netherlands. Retrieved from http://papers.tinbergen.nl/07034.pdf

Ong, C. H. (1999). Boards of directors and corporate performance: agency or stewardship theory. [Work-in-progress report]. National University of Singapore, Singapore.

Ong, C. H., \& Wan, T. W. D. (2001). Board structure, board process and board performance: a review $\&$ research agenda. Journal of Comparative International Management, 4(1), 1-25.

Pfeffer, J., \& Salancik, G. R. (1978). The external control of organizations: a resource dependence approach. New York: Harper and Row Publishers.

Pombo, C., \& Guitiérrez, L. H. (2011). Outside directors, board interlocks and firm performance: empirical evidence from Colombian business groups. Journal of Economics and Business, 63(4), 251-277. doi: 10.1016/j.jeconbus.2011.01.002

Prevost, A. K., Rao, R. P., \& Hossain, M. (2002). Board composition in New Zealand: an agency perspective. Journal of Business Finance \& Accounting, 29(5/6), 731-760. doi: 10.1111/14685957.00448

Ramos, R. G., \& Olalla, M. G. (2011). Board characteristics and firm performance in public founder and nonfounder - led family businesses. Journal of Family Business Strategy, 2(4), 220-231. doi: 10.1016/j.jfbs.2011.09.001

Rechner, P. L., \& Dalton, D. R. (1991). CEO duality and organizational performance: a longitudinal analysis. Strategic Management Journal, 12(2), 155-160. doi: 10.1002/smj.4250120206

Rhoades, D. L., Rechner, P. L., \& Sundaramurthy, C. (2000). Board composition and financial performance: a meta-analysis of the influence of outside directors. Journal of Managerial Issues, 12(1), 76-91.

Rosenstein, S., \& Wyatt, J. G. (1990). Outside directors, board independence, and shareholder wealth. Journal of Financial Economics, 26(2), 175-192. doi: 10.1016/0304-405X(90)90002-H

Rossoni, L. (2009). Governança corporativa, legitimidade e desempenho das organizações listadas na Bovespa (Tese de doutorado). Universidade Federal do Paraná, Curitiba, PR, Brasil.

Santos, R. L., \& Silveira, A. M. (2007). Board interlocking no Brasil: a participação de conselheiros em múltiplas companhias e seu efeito sobre o valor das empresas. Revista Brasileira de Finanças, 5(2), 125-163. Retrieved from http://bibliotecadigital.fgv.br/ojs/index.php/rbfin/article/viewFile/1173/264

Santos, R. L., Silveira, A. M., \& Barros, L. A. (2012). Board interlocking in Brazil: directors' participation in multiple companies and its effect on firm value and profitability. Latin American Business Review, 13(1), 1-28. doi: 10.1080/10978526.2012.673419

Setia-Atmaja, L., Haman, J., \& Tanewski, G. (2011). The role of board independence in mitigating agency problem II in Australian family firms. The British Accounting Review, 43(3), 230-246. doi: 10.1016/j.bar.2011.06.006

Shivdasani, A., \& Yermack, D. (1999). CEO involvement in the selection of new Board members: an empirical analysis. The Journal of Finance, 54(5), 1829-1853. doi: 10.1111/0022-1082.00168 
Silveira, A. Di M. da, Barros, L. A. B. C., \& Famá, R. (2003). Estrutura de governança e valor das companhias abertas brasileiras. Revista de Administração de Empresas, 43(3), 50-64. doi: 10.1590/S0034-75902003000300005

Smith, A. (1776). The wealth of nations. New York: Modern Library.

Turki, A., \& Sedrine, N. B. (2012). Ownership structure, board characteristics and corporate performance in Tunisia. International Journal of Business and Management, 7(4), 121-132. doi: 10.5539/ijbm.v7n4p121

Useem, M. (2014). The inner circle: large corporations and the rise of business political activity in the US and UK. Oxford: Oxford University Press.

Warokka, A. (2008). Ownership structures, capital structure, and firm performance: an analysis of post East Asian financial crisis (Doctoral dissertation). Universidad Autónoma de Madrid, Madrid, Espana.

Yermack, D. (1996). Higher market valuation of companies with a small board of directors. Journal of Financial Economics, 40(2), 185-211. doi: 10.1016/0304-405X(95)00844-5

Zahra, S. A., \& Pearce, J. A. (1989). Boards of directors and corporate financial performance: a review and integrative model. Journal of Management, 15(2), 291-334. doi: $10.1177 / 014920638901500208$

\section{Authors' Profiles}

Delci Grapégia Dal Vesco

Rua Universitária, 1619, Jardim Universitário, 85819-110, Cascavel, PR, Brazil. E-mail address: delcigrape@ gmail.com

Ilse Maria Beuren

UFSC, Campus Reitor João David Ferreira Lima, s/n, 88040-970, Florianópolis, SC, Brazil. E-mail address: ilse.beuren@gmail.com 